\title{
Faktor resiko mastitis subklinis pada Kambing Peranakan Etawah di Kecamatan Kokap, Kulonprogo, Yogyakarta
}

\author{
Morsid Andityas *, Clara Ajeng Artdita, Nur Ika Prihanani \\ Program Studi Kesehatan Hewan, Departemen Teknologi Hayati dan Veteriner, Sekolah Vokasi, Universitas \\ Gadjah Mada, Yogyakarta, 55281 \\ *Correspondence: morsid.andityas@gmail.com
}

Received: April 21 ${ }^{\text {th }}, 2020$; Accepted: September 28 ${ }^{\text {th }}, 2020$; Published online: November $26^{\text {th }}, 2020$

\begin{abstract}
Abstrak
Tujuan: Mastitis merupakan suatu peradangan yang terjadi pada glandula intramamari sebagai respon dari mekanisme pertahanan tubuh. Kejadian dan tingkat infeksi mastitis sangat dipengaruhi oleh berbagai macam faktor penyebab. Penelitian ini bertujuan untuk mengidentifikasi faktor-faktor resiko yang berhubungan dengan kejadian mastitis subklinis pada kambing peranakan etawah (PE) di Kecamatan Kokap, Kulonprogo, Yogyakarta.

Metode: Jenis metode yang digunakan pada penelitian ini adalah metode survei. Teknik sampling yang digunakan dalam penelitian ini adalah purposive sampling dengan jumlah 200 sampel susu segar dari kambing PE. Pengumpulan data dilakukan dengan metode wawancara (kuesioner), pengamatan langsung dan pengujian status mastitis dengan menggunakan reagen California Mastitis Test (CMT). Data penelitan ini dianalisis secara diskriptif dan analisis bivariat chi square $\left(\mathrm{X}^{2}\right)$, Odds Ratio (OR), serta Relative risk (RR).

Hasil: Hasil penelitian menunjukan bahwa faktor resiko yang berperan terhadap kejadian mastitis subklinis di Kecamatan Kokap adalah variabel umur sapih $<2$ bulan $\left(X^{2}=22,99 ; O R=21,13\right.$ dan $R R=13,2)$ dan jarak pembuangan limbah $<15 \mathrm{~m}$ dari kandang $\left(\mathrm{X}^{2}=3,98 ; \mathrm{OR}=6,52\right.$ dan $\left.\mathrm{RR}=5,44\right)$.

Kesimpulan: Variabel faktor resiko umur sapih $<2$ bulan dan jarak pembuangan limbah $<15 \mathrm{~m}$ dari kandang memiliki asosiasi kuat dengan infeksi mastitis subklinis di Kecamatan Kokap, Kulonprogo, Yogyakarta.
\end{abstract}

Kata Kunci: Mastitis; Kambing peranakan etawah; Susu; Faktor resiko

Abstract

Objective: Mastitis is an inflammation that occurs in the intramamary glands in response to the body's defenses. The incidence and extent of mastitis infections are strongly influenced by a variety of causative factors. This study aims to identify risk factors associated with the incidence of subclinical mastitis in etawah crossbreed goats in Kokap District, Kulonprogo, Yogyakarta.

Methods: The type of method used in this research was a survey method. The sampling technique used in this study was purposive sampling with 200 fresh milk samples from etawah crossbreed goats. Data collection was carried out by interview (questionnaire), direct observation and mastitis status testing using the California Mastitis Test (CMT) reagent. This research data analyzed descriptively and bivariate (chi square analysis $\left(\mathrm{X}^{2}\right)$, Odds Ratio $(\mathrm{OR})$, and Relative risk (RR)). 
Results: The results showed that the risk factors that play a role in the incidence of subclinical mastitis in Kokap District were variabel weaning age $<2$ months $\left(X^{2}=22.99 ; \mathrm{OR}=21.13\right.$ and $\left.R R=13.2\right)$ and waste disposal distance $<15 \mathrm{~m}$ from cage $\left(\mathrm{X}^{2}=3.98 ; \mathrm{OR}=6.52\right.$ and $\left.\mathrm{RR}=5.44\right)$.

Conclusions: Risk factor variables weaning age $<2$ months and waste disposal distance $<15 \mathrm{~m}$ from the cage have a strong association with subclinical mastitis infection in Kokap district, Kulonprogo, Yogyakarta.

Keywords: Mastitis; Etawah crossbreed goat; Milk; Risk factors

\section{PENDAHULUAN}

Kecamatan Kokap, Kulonprogo, Daerah Istimewa Yogyakarta merupakan salah satu daerah yang memiliki berbagai macam potensi dalam pengembangan sektor usaha ternak. Berbagai potensi seperti ketersediaan pakan hijauan, area wilayah terluas di Kabupaten Kulonprogro (7,379.950 Ha), ketinggian lokasi (memiliki ketinggian antara 8 sampai dengan $>500$ meter dpl), curah hujan dan suhu menjadi faktor-faktor pendukung dalam pembudidayaan ternak ruminansia di Kecamatan Kokap. Salah satu unggulan komoditas ternak yang ada di Kecamatan Kokap adalah usaha ternak kambing PE. Menurut data Badan Pusat Statistik Kulonprogo [1], jumlah populasi kambing pada tahu 2016 di Kecamatan Kokap, Kulonprogo sebanyak 11.727 ekor yang terdiri dari berbagai jenis kambing, termasuk kambing PE. Kambing PE merupakan hasil persilangan antara kambing etawah yang berasal dari India dengan kambing kacang yang ada di Indonesia. Karakteristik dari kambing PE yaitu sering didominasi warna rambut kombinasi putih, hitam, dan coklat; umur dewasa kelamin $18 \pm 5$ bulan; umur beranak pertama $18 \pm 0.4$ bulan; lama bunting $5 \pm 0.3$ bulan, lama birahi $18 \pm 6$ jam; Birahi setelah beranak $63 \pm 6$ hari; dan jumlah anak sekelahiran 1-2 hari [2].

Kambing PE sering dikaitkan dengan istilah kambing dwi guna, hal tersebut dikarenakan kambing PE dapat bermanfaat sebagai kambing pedaging dan kambing perah. Kambing PE pada masa laktasi ratarata mampu memproduksi susu mencapai 0,8-3 liter susu per hari tergantung masa laktasi $[2 ; 3]$. Salah satu permasalahan utama yang sering dihadapi oleh peternak perah adalah penyakit mastitis. Mastitis merupakan salah satu penyakit peradangan yang terjadi di glandula intramamari. Status mastitis secara garis besar dikelompokkan menjadi tiga macam, yaitu mastitis klinis, mastitis subklinis, dan mastitis kronis. Mastitis klinis memiliki ciri dengan muncul tanda patologis yang jelas pada ambing dengan diikuti perubahan komposisi susu secara kualitatif dan kuantitatif. Mastitis subklinis secara umum dicirikan dengan infeksi tanpa gejala klinis dengan disertai peningkatan Jumlah Sel Somatik (JSS), bahkan beberapa kasus diikuti dengan penurunan produksi susu. Kasus pada mastitis kronis memiliki ciri yang dapat masuk ke dalam sifat klinis atau subklinis dengan jangka waktu infeksi yang cukup panjang [4].

Penyakit mastitis secara umum menyebabkan kerugian ekonomi secara langsung dan tidak langsung. Kerugian ekonomi yang ditinjau dari pengukuran secara langsung adalah biaya pengobatan dan susu yang dibuang (pada beberapa kasus dalam proses pengobatan atau tidak layak dikonsumsi). Kerugian ekonomi yang ditinjau secara tidak langsung adalah komposisi susu yang berubah, produksi yang menurun akibat kerusakan atau infeksi yang sedang berlangsung, perawatan yang ekstra dalam masa pengobatan, potensi untuk dijual atau digantikan lebih awal dari masa pemeliharaan lebih tinggi dan kematian [5]. Kerugian yang disebabkan oleh kejadian mastitis tersebut dapat menjadi kendala utama bagi kemajuan industri susu khususnya peternakan kambing PE. Efesiensi pengendalian mastitis dapat dilakukan dengan mengidentifikasi informasi berdasarkan faktor-faktor resiko yang disesuaikan dengan kondisi masing-masing lapangan. Identifikasi faktor-faktor penyebab mastitis perlu dilakukan agar dapat mengembangan metode pencegahan dan pengendalian terhadap kasus mastitis [6]. Tujuan dari penelitian ini adalah untuk 
mengetahui faktor-faktor risiko yang mempengaruhi kejadian kasus mastitis pada kambing PE di Kecamatan Kokap, Kulonprogo, Yogyakarta.

\section{MATERI DAN METODE}

\section{Materi penelitian}

Materi yang digunakan dalam penelitian adalah 200 sampel susu segar yang diperoleh dari 100 ekor kambing PE. Penentuan jumlah sampel tersebut mengunakan purposive sampling dengan kriteria yaitu kambing PE yang memasuki masa laktasi dari segala umur, distribusi populasi kambing PE, dan data rekording yang lengkap. Peralatan dan bahan yang digunakan dalam penelitian ini adalah borang kuesioner, paddle, alkohol $70 \%$, reagen California Mastitis Test Bovivet ${ }^{\circledR}$ (CMT) dan cooling box.

Penelitian ini dilakukan dengan pendekatan metode survei. Metode tersebut merupakan salah satu jenis metode penelitian yang tidak melakukan perubahan terhadap variabel-variabel yang diteliti sehingga dapat melihat gambaran kondisi populasi pada satu titik waktu [7]. Kegiatan penelitian ini dilaksanakan pada bulan Maret sampai November 2018 di Kecamatan Kokap, Kulonprogo, Yogyakarta. Pengumpulan data dilakukan dengan metode wawancara, pengamatan langsung dan data hasil pengujian status mastitis dari sampel susu kambing PE.

\section{Faktor resiko}

Metode survei dengan kuesioner dilakukan untuk mengetahui hubungan manajemen pemeliharaan dan data rekording yang berpotensi sebagai faktor-faktor resiko terhadap kejadian mastitis. Pengisian kuesioner dilakukan dengan menggunakan daftar pertanyaan kepada peternak kambing PE. Jenis pertanyaan kuesioner pada penelitian ini menggunakan jenis pertanyaan dikotomi dan pilihan. Variabel bebas pada penelitian ini meliputi seluruh faktor risiko terdiri dari: frekuensi pembersihan alas kandang, frekuensi pembersihan halaman, jarak pembuangan limbah, penanganan kotoran ternak, melakukan teat dipping, menggunakan pelicin, urutan pemerahan, upaya pemisahan kambing sakit, tindakan karantina bagi kambing baru, umur sapih, umur laktasi, body condition score (BCS), frekuensi pemerahan, dan litter size. Variabel tergantung pada penelitian ini adalah hasil pengujian mastitis pada susu kambing PE dengan menggunakan CMT.

\section{Pengujian mastitis}

Pengujian status infeksi mastitis dilakukan di lokasi peternakan dengan menggunakan reagen CMT Bovivet $\AA$. Sampel susu kambing PE yang didapat dari masingmasing kuartir diuji menggunakan reagen CMT dengan perbandingan 1:1 di dalam paddle, kemudian digoyangkan secara horizontal dan perlahan-lahan selama 10-15 detik. Hasil pengujian mastitis dikelompokkan menjadi 4 kategori, yaitu kategori 0 (-) ditandai dengan tidak ada masa mengental, positif $1(+)$ ditandai dengan adanya masa sedikit mengental, positif $2(++)$ ditandai dengan masa yang mengental, dan positif $3(+++)$ ditandai dengan masa yang menyerupai gel yang sulit digerakkan $[8 ; 9]$.

\section{Analisis data}

Hasil data uji status mastitis dan manajemen peternakan dianalisis dengan statistik diskriptif, sedangkan data faktor resiko dianalisis dengan perhitungan bivariate chi square $\left(\mathrm{X}^{2}\right)$, odds ratio $(\mathrm{OR})$, dan Relative risk (RR).

\section{HASIL DAN PEMBAHASAN}

Deteksi mastitis dengan menggunakan CMT dilakukan per-kuatir pada 200 sampel susu (100 ekor kambing PE) yang ada di Kecamatan Kokap, Kulonprogo, Yogyakarta. Hasil pengujian menunjukan bahwa terdapat 15 ekor ternak PE yang ada di Kecamatan Kokap terinfeksi mastitis subklinis dari seluruh sampel populasi. Pendekatan diagnosa terhadap mastitis subklinis tersebut didasarkan pada hasil pengujian CMT dengan dibandingkan dengan penilaian katagori. Hasil pengujian mastitis pada 200 sampel susu didapatkan data, yaitu positif 0 atau tidak terinfeksi $(65 \%)$, positif $+(19 \%)$, positif ++ $(8 \%)$, dan positif $+++(8 \%)$. Berdasarkan hasil tersebut didapatkan bahwa data kambing PE 
yang terinfeksi terinfeksi kedua kuartir sebanyak 5 ekor dan yang terinfeksi hanya satu kuartir sebanyak 10 ekor. Hasil dari pengujian deteksi mastitis dengan menggunakan CMT tersebut dapat dilihat pada Gambar 1.

Hasil analisis bivariat dengan Chi Square menunjukan bahwa terdapat enam faktor resiko yang memiliki hubungan dengan mastitis subklinis, yaitu tidak dilakukan teat dipping $\left(\mathrm{X}^{2}=5,23\right)$, urutan pemerahaan yang acak $\left(X^{2}=4,85\right)$, umur sapih $<2$ bulan $\left(X^{2}=22,99\right)$, tidak dilakukan pemerahan $\left(X^{2}=5,23\right)$, jarak pembuangan limbah $<15 \mathrm{~m}$ dari kandang $\left(X^{2}=3,98\right)$ dan menggunakan pelicin $\left(X^{2}=5,68\right)$ (Tabel 2). Hasil analisis data faktor resiko lainnya seperti frekuensi pembersihan alas kandang, frekuensi pembersihan halaman, penanganan kotoran ternak, upaya pemisahan kambing sakit, tindakan karantina bagi kambing baru, umur laktasi, body condition score (BCS), dan litter size tidak memiliki hubungan dengan mastitis subklinis. Berdasarkan analisis tersebut kemudian dilanjutkan ke analisis OR dan RR, hasil analisis menunjukkan bahwa terdapat dua faktor resiko yang memiliki asosiasi kuat yaitu faktor resiko umur sapih $<2$ bulan $(\mathrm{OR}=21,13$; $R R=13,2)$ dan jarak pembuangan limbah $<15 \mathrm{~m}$ dari kandang $(\mathrm{OR}=6,52 ; \mathrm{RR}=5,44)$ (Tabel 2).

Sel somatik dapat digunakan sebagai salah satu monitor kondisi kesehatan ambing dan kualitas susu. Kejadian peningkatan JSS merupakan aktifitas inflamasi sebagai mekanisme fisiologi tubuh terhadap suatu respon tertentu. Komposisi sel somatik yang terdiri dari makrofag, limfosit, Polymorphonuclear (PMN), neutrofil dan khususnya leukosit yang dianggap sebagai indikator terjadinya inflamasi ambing [8]. Kejadian mastitis biasanya diikuti dengan peningkatan JSS, hal tersebut dapat menjadi salah satu parameter dalam pendekatan diagnosa mastitis [10]. JSS dapat diperiksa melalui dua skema pemeriksaan yaitu pemeriksaan langsung (dengan metode breed, alat Coulter Counter dan Fosomatic) dan pemeriksaan tidak langsung (dengan metode CMT, Whiteside test, tes IPB-1 dan pemeriksaan sejenis lainnya). Pendekatan pemeriksaan langsung umumnya digunakan dalam studi eksperimental atau observasi sedangkan pada pendekatan tidak langsung umumnya digunakan sebagai program pengendalian mastitis dan studi survei [11].

Pengujian CMT merupakan salah satu pengujian cepat, bersifat subjektif dan mudah digunakan sebagai alat screening pendekatan diagnosa awal terhadap infeksi mastitis. Infeksi mastitis pada kambing secara umum mirip yang terjadi pada sapi tetapi terdapat perbedaan penilaian katagori terhadap pemeriksaan status infeksi mastitis pada kambing jika dibandingkan dengan pemeriksaan status infeksi mastitis pada sapi [8]. Menurut Suwito [12], kambing PE didiagnosis mastitis subklinis apabila hasil pengujian CMT menunjukan katagori positif 2 $(++)$ dan positif $3(+++)$, sedangkan pada kategori $0 \quad(-)$ dan positif $1 \quad(+)$ tidak dimasukkan dalam status mastitis. Perbedaan antara komposisi penyusun susu kambing PE

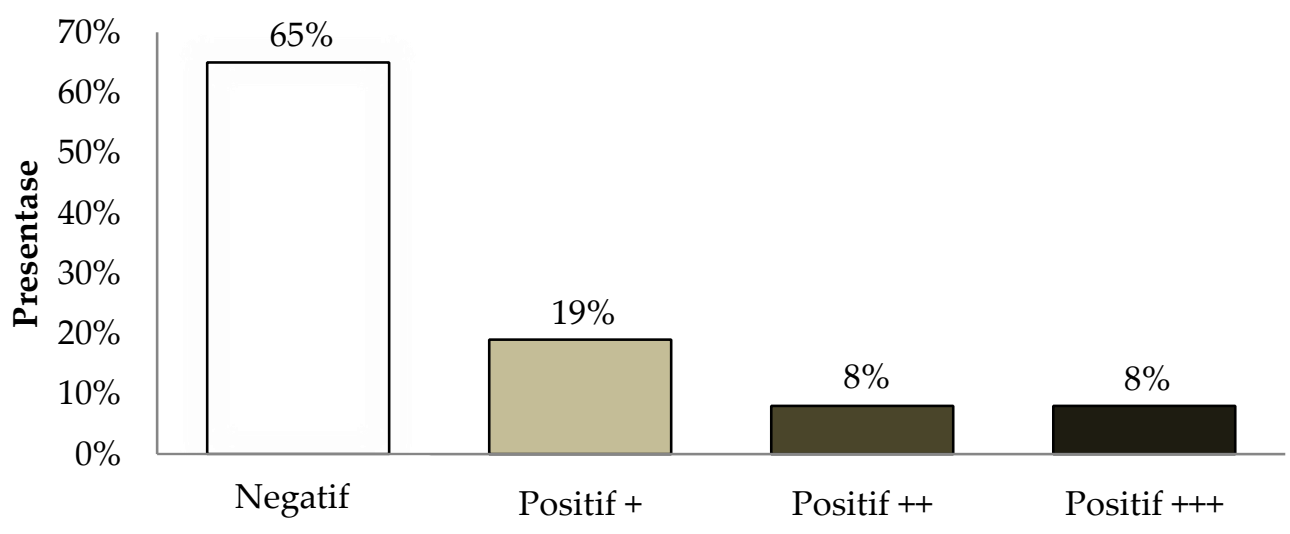

Hasil Skor CMT

Gambar 1. Deteksi mastitis pada kambing PE dengan pengujian California Masitits Test di Kecamatan Kokap, Kulonprogo, Yogyakarta ( $\mathrm{n}=200$ sampel susu) 
dengan susu sapi menjadi faktor utama dalam menetukan katagori status mastitis dipengujian CMT. Susu kambing memiliki nilai yang lebih tinggi terhadap Jumlah Sel Somatik (JSS), Cytoplasmic Particles (CP) dan Polymorphonuclear (PMN) jika dibandingkan dengan susu sapi. Jumlah sel somatik susu kambing pada kondisi tidak terinfeksi mastitis umumnya memiliki jumlah antara $270 \times 10^{3}$ hingga $2.000 \times 10^{3} \mathrm{SC} \mathrm{mL}^{-1}$, sedangkan pada domba dan sapi JSS dapat mencapai diantara $10 \times 10^{3}$ hingga $200 \times 10^{3} \mathrm{SC}^{-1}[8 ; 11]$.

Kejadian mastitis dipengaruhi oleh tiga komponen utama yaitu paparan mikrobia, faktor-faktor resiko lingkungan dan mekanisme fisiologi pertahanan tubuh terutama ambing. Pendekatan program pengendalian mastitis saat ini lebih ditekankan pada praktik higienis dan manajemen praktis dalam pencegahan terhadap infeksi intramamari [13]. Studi pada penelitian ini difokuskan untuk menentukan faktor resiko terhadap kejadian mastitis subklinis berdasarkan studi survei pada kambing PE di Kecamatan Kokap, Kulonprogo. Hasil analisis bivariat pada penelitian ini menunjukan bahwa variabel umur sapih $<2$ bulan menjadi salah satu faktor dari kejadian mastitis subklinis di Kecamatan Kokap. Faktor resiko kambing PE yang dilakukan penyapihan pada umur $<2$ bulan memiliki kekuatan 21,13 kali sebagai penyebab kejadian mastitis subklinis dibandingkan dengan kambing PE yang dilakukan penyapihan pada umur $>2$ bulan. Berdasarkan data kuesioner sebagian besar penyapihan tersebut bertujuan agar kambing PE dapat memasuki masa kering sebagai upaya mempersiapkan kondisi kambing PE untuk segera dikawinkan kembali. Hasil

Tabel 1. Manajemen pemeliharaan dan presentase kejadian mastitis subklinis pada kambing PE yang ada di Kecamatan Kokap, Kulonprogo, Yogyakarta

\begin{tabular}{|c|c|c|c|c|}
\hline \multirow{2}{*}{ No. } & \multirow{2}{*}{ Variabel } & \multirow{2}{*}{$\frac{\text { Total ternak }(\mathrm{n}=100)}{\mathrm{N}}$} & \multicolumn{2}{|c|}{ Mastitis subklinis $(\mathrm{n}=15)$} \\
\hline & & & $\mathrm{N}$ & Presentase $(\%)$ \\
\hline \multirow[t]{4}{*}{1.} & Frekuensi pembersihan alas kandang & & & \\
\hline & 1 hari sekali & 89 & 14 & 93,33 \\
\hline & 2 hari sekali & 6 & 0 & 00,00 \\
\hline & $\geq 3$ hari sekali & 5 & 1 & 6,67 \\
\hline \multirow[t]{4}{*}{2.} & Frekuensi pembersihan halaman kandang & & & \\
\hline & 1 hari sekali & 82 & 14 & 94,33 \\
\hline & 2 hari sekali & 14 & 0 & 0,00 \\
\hline & $>3$ hari sekali & 4 & 1 & 6,67 \\
\hline \multirow[t]{3}{*}{3.} & Jarak pembuangan limbah & & & \\
\hline & $>15 \mathrm{~m}$ dari kandang & 28 & 1 & 6,67 \\
\hline & $<15 \mathrm{~m}$ dari kandang & 72 & 14 & 93,33 \\
\hline \multirow[t]{4}{*}{4.} & Penanganan kotoran ternak & & & \\
\hline & Ditimbun pada lubang tanah & 49 & 15 & 100,00 \\
\hline & Disimpan dalam karung tertutup & 23 & 0 & 0,00 \\
\hline & Ditimbun diatas permukaan tanah & 28 & 0 & 0,00 \\
\hline \multirow[t]{3}{*}{5.} & Melakukan Teat Dipping & & & \\
\hline & Dilakukan Teat Dipping & 40 & 10 & 66,67 \\
\hline & Tidak Dilakukan Teat Dipping & 60 & 5 & 33,33 \\
\hline \multirow[t]{3}{*}{6.} & Menggunakan pelicin & & & \\
\hline & Ya & 39 & 10 & 66,67 \\
\hline & Tidak & 61 & 5 & 33,33 \\
\hline
\end{tabular}


Lanjutan Tabel 1.

\begin{tabular}{llccc}
\hline \multirow{2}{*}{ No. } & Variabel & \multicolumn{2}{c}{ Total Ternak $(\mathrm{n}=100)$} & \multicolumn{2}{c}{ Mastitis subklinis $(\mathrm{n}=15)$} \\
\cline { 3 - 5 } & & $\mathrm{N}$ & $\mathrm{N}$ & Presentase $(\%)$ \\
\hline
\end{tabular}

7. Urutan pemerahan

Acak

Sehat ke sakit

65

35

65

35

Tidak

9. Tindakan karantina bagi kambing baru

Ya

Tidak

10. Umur sapih

$>2$ bulan

$<2$ bulan

11. Umur laktasi

$$
\geq 3 \text { tahun }
$$$$
<3 \text { tahun }
$$

12. Body Condition Score

$$
\leq 2
$$$$
\geq 3
$$

13. Frekuesi Pemerahan

$$
\begin{aligned}
& \text { dilakukan } 1 \text { kali (setiap hari) } \\
& \text { dilakukan } \geq 2 \text { kali (setiap hari) } \\
& \text { tidak dilakukan pemerahan }
\end{aligned}
$$

\section{Litter Size}

\begin{tabular}{l}
1 \\
2 \\
$>2$ \\
\hline
\end{tabular}

penelitian ini sesuai dengan Suwito [12] yang melaporkan bahwa kambing PE yang dilakukan penyapihan $<1$ bulan mempunyai kekuatan 2,12 kali sebagai penyebab mastitis subklinis di Kabupaten Sleman, Yogyakarta. Kondisi penelitian lain melaporkan bahwa pada masa penyapihan anak sapi terdapat $66,1 \%$ dari sapi induk terinfeksi mastitis dengan tingkat infeksi pada ambing sebesar $31,7 \%$ dari keseluruhan sampel populasi [14].

Glandula intramamari memiliki beberapa faktor penting dalam proses pertahanan tubuh secara natural dari infeksi mastitis. Faktor penting tersebut salah satunya adalah laktoferin, laktoferin memiliki kemampuan untuk menghambat pertumbuhan beberapa bakteri melalui ikatan besi secara reversibel [12]. Laktoferin dapat juga berfungsi sebagai imunomodulator untuk leukosit dan dapat bersinergi dengan IgG1 dalam melawan bakteri Eschericia coli dan Klebsiella $s p$. Peningkatan leukosit yang kondusif menyebabkan konsentrasi lemak dan kasein dalam sekresi susu menurun, selain itu konsentrasi imunoglobulin juga menjadi lebih tinggi pada masa tidak laktasi. Kondisi terpenting pada masa kering adalah tertutupnya saluran puting oleh subatan keratin sebagai penghalang fisik masuknya agen patogen [15]. 
Faktor resiko saat memasuki masa kering menjadi salah satu faktor yang diperhitungkan dalam prediposisi infeksi mastitis. Sebagian besar infeksi mastitis subklinis terjadi selama awal periode masa kering, dua bulan pertama periode laktasi, dan dua minggu menjelang waktu beranak yang kemudian dapat diikuti dengan infeksi dari lingkungan [8]. Infeksi mastitis subklinis dapat terjadi dikarenakan pada masa-masa tersebut ambing menjadi lebih peka terhadap respon mikrobia dari lingkungan. Fase kritis infeksi mastitis pada masa kering dibagi menjadi tiga tahapan, yaitu involusi awal, steady-state involution dan kolostrogenesis (transisi). Fase involusi awal merupakan kondisi ambing memasuki tahapan yang sangat rentan terhadap infeksi. Kondisi tersebut dikarenakan terjadi penghentian pemerahan, tidak ada aktivitas treatment dipping, proses sanitasi puting terhenti dan terjadi tansisi yang lambat menuju fase steady-state involution. Kegiatan penghentian pemerahan tersebut secara tidak langsung juga berdampak pada peningkatan tekanan pada ambing akibat kondisi susu yang penuh pada ambing [15]. Hasil data pada penelitian ini sesuai dengan gagasan tersebut yang menunjukan bahwa variabel tidak dilakukan pemerahan pada ambing memiliki hubungan dengan kejadian mastitis subklinis $\left(X^{2}=4,85\right)$, akan tetapi hubungan tersebut khusus pada penelitian ini memiliki kekuatan yang lemah $(\mathrm{OR}=0,29$ dan $\mathrm{RR}=0,36)$. Data hubungan yang lemah tersebut dimungkinkan karena pada variabel tidak dilakukan pemerahan memiliki presentase terinfeksi mastitis yang rendah $(33,33 \%)$.

Fase involusi awal dan steady-state involution merupakan kondisi fisiologis normal tubuh saat menghadapi awal masa kering. Adaptasi pada fase involusi awal menimbulkan efek stres pada ambing sehingga secara tidak langsung berefek pada fisiologi hormonal dan pertahanan tubuh. Kondisi stres pada ambing juga diakibatkan karena kelenjar ambing harus menyerap susu dan jutaan sel-sel mati yang telah disekresikan. Keadaan-keadaan tersebut akan menyebabkan kondisi ambing akan sangat rentan terkena infeksi baru [7]. Pergerakan menuju ke fase steady-state involution yang lambat berakibat pada penurunan proteksi dari lactoferin dan imunoglobulin, selain itu juga diikuti dengan peningkatan lemak dan kasein. Peningkatan lemak dan kasein tersebut berakibat pada penghambatan fungsi leukosit. Fase steady-state involution merupakan kondisi involusi sempurna sehingga pada tahap ini kondisi ambing siap bertahan terhadap infeksi yang akan menyerang. Fase kolostrogenesis (transisi) memiliki ciri glandula mamari menjadi lebih rentan terhadap infeksi, sumbatan keratin menjadi rusak, dan fungsi leukosit menjadi terganggu [15].

Kondisi higienis atau kebersihan lingkungan tempat tinggal yang rendah berpengaruh terhadap kenaikan insidensi pada infeksi mastitis [16]. Hasil penelitian ini menunjukan bahwa variabel jarak pembuangan limbah $<15 \mathrm{~m}$ dari kandang memiliki hubungan dengan kejadian mastitis subklinis $\left(X^{2}=3,98\right)$. Hasil tersebut kemudian dilanjutkan pada analisis OR dan RR didapatkan hasil yang berturut-turut sebagai berikut: variabel jarak pembuangan limbah $<15 \mathrm{~m}$ menyebabkan tejadinya kejadian mastitis subklinis 6,52 kali lebih cepat daripada variabel jarak pembuangan limbah $>15 \mathrm{~m}$, sedangkan resiko terjadinya mastitis subklinis akibat dari variabel jarak pembuangan limbah $<15 \mathrm{~m}$ sebesar 5,44 kali lebih cepat daripada variabel jarak pembuangan limbah $>15 \mathrm{~m}$. Sanitasi lingkungan pemerahan dan perhatian yang kurang terhadap kesehatan glandula mamari menjadi faktor penting yang berkontribusi terhadap prevalensi mastitis. Kotoran ternak yang dibuang dengan menimbun diatas permukaan tanah dan tempat pembuangan limbah yang letaknya tidak jauh dari kandang menyebabkan lingkungan kandang menjadi tercemar. Keadaan tersebut akan menyebabkan mikroorganisme akan dapat tumbuh dengan baik sehingga secara tidak langsung akan berpengaruh terhadap kesehatan ternak, terutama mastitis subklinis [17].

Proses infeksi mastitis dimulai dari mikroorganisme masuk ke kelenjar ambing melalui teat meatus yang masih terbuka setelah proses pemerahan ataupun menyusui. Agen tersebut menyebar dan berkembang ke alveoli 
sehingga menyebabkan kerusakan pada susu yang dihasilkan, selain itu invasi yang terjadi akan menimbulkan reaksi peradangan dengan ditandai dengan infiltrasi selsel radang di jaringan yang terinfeksi. Beberapa kasus pada infeksi akut menyebabkan terjadinya pembentukan jaringan ikat pada area infeksi, hal tersebut merupakan salah satu mekanisme tubuh dalam memperbaiki jaringan yang rusak [17]. Proses perbaikan tersebut secara tidak langsung berdampak pada penurunan produksi susu hingga ambing tidak dapat memproduksi susu.

Variabel tidak dilakukan teat dipping $\left(X^{2}=5,23\right)$ memiliki hubungan dengan kejadian mastitis subklinis, akan tetapi hubungan tersebut pada penelitian ini memiliki kekuatan yang lemah $(\mathrm{OR}=0,27$ dan $\mathrm{RR}=0,33)$ (Tabel 2). Hubungan yang lemah tersebut dimungkinkan karena pada variabel tidak dilakukan teat dipping memiliki presentase infeksi mastitis yang rendah sebesar 33,33\%. Variabel yang dilakukan teat dipping sebelum dan sesudah pemerahan, mencuci tangan sebelum pemerahan, dan ambing dikeringkan setelah dicuci bersih menunjukan hasil tidak memiliki hubungan yang signifikan dengan infeksi mastitis pada sapi perah [16]. Kondisi tersebut menunjukan bahwa perilaku aktifitas higienis yang baik dalam pemeliharaan dapat menjadi salah satu faktor dalam mencegah infeksi mastitis.

Lubang puting atau teat meatus pasca pemerahan membutuhkan waktu dalam proses penutupan, waktu proses penutupan tersebut bervarisi berdasarkan kondisi fisiologi tubuh dan umur kambing. Jumlah sel leukosit, antibodi dan enzim pasca pemerahan berada dalam level jumlah yang rendah, hal ini dikarenakan zat-zat tersebut ikut terperah saat proses pemerahan. Teat meatus dari ambing akan tetap terbuka hingga 2-3 jam setelah pemerahan. Kondisi-kondisi tersebut mengakibatkan ambing yang telah dilakukan pemerahan menjadi sangan rentan terhadap infeksi [17]. Strategi yang dapat dilakukan agar memberikan waktu teat meatus menutup adalah salah satunya dengan pemberian pakan dan minum setelah melakukan pemerahan. Tujuan dari upaya tersebut adalah memberi waktu bagi teat meatus dapat menutup. Posisi berdiri mengurangi resiko teat meatus bersentuhan dengan lingkungan kandang [18].

Teat dipping yang dilakukan sebelum dan sesudah pemerahan memiliki tujuan untuk mencegah terjadinya infeksi Intramammary [15]. Duralioglu [19] mengatakan bahwa perlakuan pada teat dipping sebelum dan sesudah pemerahan menghasilkan penurunan jumlah sel somatik serta menurunkan tingkat infeksi intramammary. Teat dipping dengan menggunakan disinfektan atau antiseptik berperan dalam mencegah terjadinya infeksi bakteri pada ambing. Antiseptik yang dapat digunakan sebagai teat dipping adalah iodine dan Chlorin, sedangkan disinfektan yang biasa digunakan adalah benzalkonium cloride, chlorhexidine, dan isopropanol [20]. Penggunaan disinfektan atau antiseptik perlu disesuaikan dengan anjuran dan dosis yang tepat. Pemberian disinfektan yang berlebihan menyebabkan terjadinya hiperkeratosis, iritasi kulit puting, puting menjadi kasar, luka, dan pecah-pecah sehingga ambing mudah terinfeksi oleh mikroorganisme. Pemberian disinfektan dengan larutan chlorhexidine pada proses teat dipping memiliki tingkat signifikan terhadap

Tabel 2. Analisis faktor risiko penyebab mastitis subklinis pada kelompok ternak PE yang ada di Kecamatan Kokap, Kulonprogo, Yogyakarta

\begin{tabular}{lccc}
\hline \multicolumn{1}{c}{ Variabel Faktor Risiko } & X2 & Odds Ratio (OR) & Relative Risk (RR) \\
\hline Tidak dilakukan Teat Dipping & 5,23 & 0,27 & 0,33 \\
Urutan pemerahan yang acak & 4,85 & 0,29 & 0,36 \\
Umur sapih $<2$ bulan & $22,99^{*}$ & $21,13^{*}$ & $13,20^{*}$ \\
Tidak dilakukan pemerahan & 5,23 & 0,27 & 0,33 \\
Jarak pembuangan limbah $<15$ m dari kandang & $3,98^{*}$ & $6,52^{*}$ & $5,44^{*}$ \\
Menggunakan pelicin & 5,68 & 0,26 & 0,32 \\
\hline
\end{tabular}

Keterangan: *asosiasi kuat 
rata-rata skor hiperkeratosis jika dibandingkan dengan yang tidak diberi perlakuan [21; 22].

Variabel urutan pemerahan yang acak memiliki hubungan dengan kejadian mastitis subklinis $\left(X^{2}=4,85\right)$. Tabel 2 menunjukan bahwa variabel urutan pemerahan yang acak memiliki kekuatan asosiasi yang lemah $(\mathrm{OR}=0,29$ dan $\mathrm{RR}=0,36)$. Hasil penelitian pada Tabel 1 menunjukan bahwa sebanyak 65 ekor kambing PE dilakukan pemerahan acak, sedangkan pemerahan dari sehat ke sakit sebanyak 35 ekor. Pemerahan acak menjadi salah satu faktor terhadap transmisi mikrooganisme dari ambing yang terinfeksi mastitis ke ambing yang sehat. Manajemen pemerahan ambing dalam upaya menghindari infeksi silang antara yang sakit dan sehat harus dilakukan dengan cara memerah ambing dari hewan yang sehat ke hewan yang sakit. Tangan pemerah yang tidak steril menjadi salah satu faktor yang berpengaruh terhadap kejadian mastitis [23]. Pemerahan dengan menggunakan tangan dan sanitasi yang buruk menjadi faktor yang dominan terhadap infeksi dari agen patogen sehingga menyebabkan kejadian infeksi mastitis [24].

Infeksi mastitis dimungkinkan melalui transmisi dari hewan yang terinfeksi ke hewan yang tidak terinfeksi melalui tangan pemerah, khususnya ambing yang sering diberi perlakuan pelicin selama pemerahan [25]. Penggunaan pelicin seperti minyak atau vaselin saat melakukan pemerahan akan menjadi kendala saat proses sanitasi, hal tersebut disebabkan karena senyawa pelicin saat pemerahan akan menyelimuti permukaan puting. Kondisi tersebut apabila pembersihan tidak optimal maka berpengaruh pada sanitasi sehingga organisme dapat tumbuh di permukaan puting. Hasil analisis menunjukan bahwa variabel peternak yang menggunakan pelicin saat pemerahan memiliki hubungan dengan kejadian mastitis subklinis pada ternak kambing PE di Kecamatan Kokap $\left(X^{2}=5,68\right)$, akan tetapi hubungan tersebut memiliki kekuatan yang lemah dengan nilai $\mathrm{OR}=0,26$ dan $\mathrm{RR}=0,32$. Penggunaan vaselin memang tidak dianjurkan dalam pemerahan, hal tersebut sesuai dengan
Kepmentan nomor 422/Kpts/O.210/7 [26] yang mengatakan bahwa kondisi yang perlu diperhatikan dalam proses pemerahan salah satunya tidak menggunakan vaselin atau minyak sebagai pelicin, pemerah harus selalu bersih tangannya selama pemerahan, sebelum pemerahan mencuci tangan dengan sabun, dan memakai pakaian yang bersih.

\section{KESIMPULAN}

Kesimpulan hasil analisis variabel menunjukan bahwa terdapat dua faktor resiko yang memiliki asosiasi kuat terhadap infeksi mastitis subklinis di Kecamatan Kokap, Kulonprogo, Yogyakarta. Variabel faktor resiko tersebut antara lain variabel umur sapih $<2$ bulan $\left(X^{2}=22,99 ; O R=21,13\right.$ dan $\left.R R=13,2\right)$ dan jarak pembuangan limbah $<15 \mathrm{~m}$ dari kandang $\left(X^{2}=3,98 ; O R=6,52\right.$ dan $\left.R R=5,44\right)$.

\section{KONFLIK KEPENTINGAN}

Penulis menayatakan tidak ada konflik kepentingan dengan pihak manapun terkait materi yang ditulis dalam naskah ini.

\section{UCAPAN TERIMA KASIH}

\begin{tabular}{|c|c|}
\hline & mengucapkan \\
\hline rimakasih & kepada Sekolah \\
\hline $\begin{array}{l}\text { Universitas } \\
\text { memberikan } \\
\text { pemandatan }\end{array}$ & $\begin{array}{ccc}\text { Gadjah } & \text { Mada yang telah } \\
\text { dana hibah penelitian } & \text { kontrak } \\
\text { dengan nomor kon }\end{array}$ \\
\hline & rogran \\
\hline & Tek \\
\hline $\begin{array}{l}\text { ayati dan } \\
\text { nulis samp }\end{array}$ & $\begin{array}{l}\text { Veteriner. Terimakasih } \\
\text { spaikan kepada Dinas }\end{array}$ \\
\hline & esh \\
\hline & $\begin{array}{l}\text { yan } \\
\end{array}$ \\
\hline
\end{tabular}

\section{DAFTAR PUSTAKA}

1. Kulonprogokab BPS. [Internet]. Data Populasi Ternak Kulon Progo. [cited 2020 Agust 25]. Available from: https://kulonprogokab.bps.go.id/LinkTabl eDinamis/view/id/125.

2. Keputusan Menteri Pertanian Republik Indonesia. Keputusan Menteri Pertanian 
Nomor:695/Kpts/PD.410/2/2013 tentang penetapan rumpun kambing peranakan etawah [Internet]. Kementan.; c2013 [cited 2020 Feb 17]. Available from: http://bibit.ditjenpkh.pertanian.go.id/sites/ default/files/Kambing\%20PE.pdf

3. Febriana D. N., Diah W. H., dan Priyo S. 2018. Korelasi ukuran badan, volume ambing dan produksi susu kambing Peranakan Etawah (PE) di Kecamatan Turi, Kabupaten Sleman, Yogyakarta. Jurnal Ilmu-Ilmu Peternakan 28 (2): 134 - 140. DOI: 10.21776/ub.jiip.2018.028.02.06.

4. Arce, C., dan R. E. Vicente. 2016. Factors affecting somatic cell count in dairy goats: A review. Spanish Journal of Agricultural Research 12(1): 133-150. Doi: 10.1016/09214488(92)90014-U.

5. Blowey R., and Peter E. 2010. Mastitis Control in Dairy Herds. $2^{\text {nd }}$ edition. CAB International, London, UK.

6. Wicaksono, A., dan Mirnawati, S. 2016. Prevalensi mastitis subklinis dan evaluasi mikrobiologis susu peternakan rakyat di Boyolali. Journal ACTA Veterinaria Indonesiana 4 (2): 51-56. Doi: 10.29244/avi.4.2.51-56.

7. Siregar, S. 2014. Metode Penelitian Kuantitatif Dilengkapi Dengan Perbandingan Perhitungan Manual \& SPSS. Cetakan ke-2. Kencana Prenadamedia Group, Jakarta.

8. Radostits, M. O., C. C. Gray, W. H. Kenneth, and D. C. Peter. 2006. Veterinary Medicine, A Textbook of the Diseases of Cattle, Sheep, Pigs, Goats and Horses. Elsevier Health Sciences ${ }_{L}$ London.

9. Nisa, H. C., P. Bambang, D. T. Tita, H. Mas'ud, S. Romziah, and H. Nenny. 2019. Analisis of factor affecting subclinical and clinical mastitis in dairy cow (case study in the Cooperative Agribusiness Dana Mulya Pacet, Mojokerto). Ovozoa 8(1). Doi: 10.20473/ovz.v8i1.2019.66-70.

10. Haenlein, G. F. W. 2002. Relationship of somatic cell counts in goat milk to mastitis and productivity. Journal of Elsevier Science 45(2):163-178. DOI: 10.1016/S09214488(02)00097-4.

11. Sudarwanto, M., dan Sudarnika, E. 2008. Hubungan antara $\mathrm{pH}$ susu dengan jumlah sel somatik sebagai parameter mastitis subklinik. Media Peternakan 31 (2): 107-113

12. Suwito, W., S. N. Widagdo, S. Bambang, dan E. T. H. W. Agnesia. 2014. Faktorfaktor risiko mastitis subklinis pada kambing peranakan etawah di Kabupaten Sleman, Yogyakarta. Jurnal Veteriner 15(1): 130-138.

13. Leelahapongsathon K., Tipapun P., Wasana C. and Witaya. 2016. Factors in dry period associated with intramammary infection and subsequent clinical mastitis in early postpartum cows. AsianAustralasian Journal of Animal Sciences (29): 580-585 DOI: 10.5713/ajas.15.0383

14. Litwińczuk, Z., J. Król, and A. Brodziak. 2015. Factors determining the susceptibility of cows to mastitis and losses incurred by producers due to the disease-a review. Annals of Animal Science 15(4): 819831. DOI: 10.1515/aoas-2015-0035

15. Bradley A J., dan Green M.J. 2004. The importance of the nonlactating period in the epidemiology of intramammary infection and strategies for prevention. Vet Clin North Am-Food Anim Pract. (20): 547568 DOI: $10.1016 /$ j.cvfa.2004.06.010

16. Saifudeen, M. Safeer, Kerala, R. Venkataramanan, and N. Tamil. 2018. Relationship of risk factors with incidence of mastitis in cows. Journal of Entomology And Zoology Studies 16(2): 2397-2402.

17. Nurhayati, I. S., dan Martindah E. 2015. Pengendalian Mastitis Subklinis Melalui Pemberian Antibiotik Saat Periode Kering Pada Sapi Perah. Wartazoa 25 (2): 65-74. DOI: 10.14334/wartazoa.v25i2.1143.

18. Sharif, Aamir, U. C. Muhammad, S. Marine, and M. Ghulam. 2009. Mastitis Control in Dairy Production. Journal Of Agriculture and Social Sciences 5(3): 102105. Doi: 09-005/ZAP/2009/5-3-102-105.

19. Duralioglu, A., B. Ayhan, S. Sackin, C. Mehmet, and A. Mehmet. 2014. The effects of pre-milking and post-milking teat disenfection in goats on udder health and milk quality. Journal of Ankara University Veteriner 61: 107-110. Doi: 10.1501/Vetfak_0000002613.

20. Mahardhika, O., Sudjatmogo, dan T. H. Suprayogi. 2012. Tampilan total bakteri 
dan ph pada susu kambing perah akibat dipping disenfektan yang berbeda. Animal Agriculture Journal 1(1): 819-194.

21. Gleeson, D. E., W. J. Meaney, E. J. O'Callaghan, and M. V. Rath. 2004. Effect of teat hyperkeratosis on somatic cell counts of dairy cows. International Journal of Applied Research in Veterinary Medicine 2(2): 115-122.

22. Neijenhuis F., H. W. Barkema, H. Hogeveen, and J. P. T. M. Noorhizen. 2001. Relationship between teat-end callosity and occurrence of clinical mastitis. Journal American Dairy Science Association 84:2664-2672. Doi: $10.3168 /$ jds.S00220302(01)74720-0.

23. Suryowardojo, P. 2012. Penampilan Kandungan Protein dan Kadar Lemak Susu Pada Sapi Perah Mastitis Friesian Holstein. The Journal of Experimental Life Science 2(1): 42-48. Doi: 10.21776/ ub.jels.2012.002.01.07.
24. Karimuribo, E. D., J. L. Fitzpatrick, E. S. Swai, C. Bell, M. J. Bryant, N. H. Ogden, D. M. Kambarage, and N. P. French. 2008. Prevalence of Subclinical Mastitis and Associated Risk Factors in Smallholder Dairy Cows in Tanzania. Veterinary Record 163, 16-21. Doi: 10.1136/vr.163.1.16. 25. Mustafa, S. Yasser, Farhat A. Nazir, Z. Tooba, R. C. Sana, and Z. Vetristo. 2011. Pevalence and Antibacterial Susceptibility In Mastitis In Buffalo And Cow In And Around The District Lahore-Pakistan. Pakistan Journal of Pharmacy 24: 29-33. Doi: 10.14456/ku-bufbu.2013.42.

26. Keputusan Menteri Pertanian Republik Indonesia. Keputusan Menteri Pertanian Nomor: 422/Kpts/O.210/7/2001 tentang pedoman budidaya ternak sapi perah yang baik (Good Farming Practice) [Internet]. Kementan.: c2001 [cited 2020 February 19]. Available from: https://peraturan.bkpm. go.id/jdih/front/index/110/30. 